\title{
Archiwalne materiały kartograficzne źródłem do rekonstrukcji przestrzeni dawnych wsi w strefie zabudowy miejskiej
}

\section{Kamil Nieścioruk}

$\mathbf{P}$ drugiej wojnie światowej nastąpiły w Polscegłębokie zmiany społeczno-gospodarcze, a nowa sytuacja często pociągała za sobą szybszy niż dotychczas rozwój terytorialny miast oraz wzrost liczby ich ludności. Organizmy miejskie wchłaniały historyczne wsie i przedmieścia, pozostające dawniej poza ich granicami administracyjnymi. Proces ten powodował wyraźne przekształcenia krajobrazu zwłaszcza, że w większości nowo włączane tereny przeznaczane były pod zabudowę przemysłową lub, typową dla powojennego budownictwa mieszkaniowego, wielorodzinną zabudowę wielkopłytową. W ten sposób pozornie znikała dawna przestrzeń, choć - jak zostanie to pokazane w niniejszym artykule - pozostało wiele śladów, materiałów i wskazówek pozwalających ją odtworzyć.

Zjawisko, podobne jak to opisywane powyżej, miało też miejsce w Lublinie, który po wojnie znalazł się w nowym położeniu, stając się największym miastem Polski po wschodniej stronie Wisły i ponadregionalnym ośrodkiem ciążenia. W 1939 r. miasto zamieszkiwało ponad 120 tysięcy mieszkańców, a po wojnie stan ten osiągnięto już w 1953 r. Po kolejnych 9 latach liczba mieszkańców Lublina przekroczyła 200 tysięcy, a pod koniec istnienia PRL - 350 tysięcy ${ }^{1}$. Pociągało to za sobą rozwój terytorialny miasta i włączanie w granice Lublina dawnych osad podmiejskich o ukształtowanym charakterze (Wrotków i część Dziesiątej - 1954 r.) oraz terenów wsi i gruntów rolniczych zajmowanych przez powstające spółdzielnie mieszkaniowe (pierwsze osiedla Lubelskiej Spółdzielni Mieszkaniowej zasiedlono pod koniec lat 50., w latach 70. powstały wielkie dzielnice mieszkaniowe - Czechów i Czuby). Artykuł ten analizuje jeden z takich przypadków na przykładzie dzi- siejszych osiedli Łęgi i Ruta na gruntach dawnej wsi Rury Wizytkowskie i wsi sąsiednich - Rur Jezuickich i Bonifraterskich (nazwa wsi pochodzi od XVI-wiecznych wodociągów miejskich przebiegających przez ten teren).

\section{Źródła i materiały}

Radykalne zmiany krajobrazu nastąiiły dość gwałtownie i w niedalekiej przeszłości, co pozwala odtworzyć informacje o dawnej przestrzeni na podstawie różnych po względem typu i aktualności źródeł, które można wzajemnie konfrontować. Podstawowym zagadnieniem, które pojawia się przy rekonstrukcji nieodległego czasowo krajobrazu historycznego jest pytanie, czy w obecnej przestrzeni znajdują się elementy tegoż krajobrazu i w jakim stopniu są one zachowane i osadzone w dawnym kontekście. Odpowiedź na to pytanie dać moga przede wszystkim dawne mapy topograficzne. W historii kartografii rzadko przedmiotem badań są obiekty dwudziestowieczne, zwłaszcza mapy arkuszowe (seryjne). Kilka czynników powoduje jednak, że można i wobec takich map użyć określenia „dawne” (niejako przypisującego je domenie historii kartografii właśnie, w odróżnieniu od określenia „stare”, które wskazuje jedynie na wiek i aktualność mapy, a nie jej znaczenie jako elementu w procesie rozwoju sztuki sporządzania map). Przede wszystkim pamiętać należy, że powojenne mapy topograficzne okresu PRL powstawały w zupełnie innych warunkach. Ich treść była często ograniczana cenzurą, ich obecność na rynku była znikoma, a dostępność do celów cywilnych obłożona licznymi zastrzeżeniami.

${ }^{1}$ T. Radzik i in., Lublin. Dzieje miasta, t. 2, XIX i XX wiek, Lublin 2000 s. $179,426,573$. 
W przypadku map cywilnych („gospodarczych") cenzura dotyczyła nie tylko treści, ale i formy, a nawet samych podstaw matematycznych mapy (można tu właściwie mówić o opracowaniach parakartograficznych $)^{2}$. Problem ten dotykał jednak w tym czasie nie tylko specjalistycznych opracowań kartograficznych (za takie można uznać mapy topograficzne), ale i publikacji przeznaczonych dla masowego odbiorcy, w tym turysty (plany miast, mapy atrakcyjnych regionów) ${ }^{3}$. Wszystko to pozwala spojrzeć na mapy okresu 1945-1989 jako na zabytki swojej epoki, dokumentujące stan rozwoju kartografii i jej związek z sytuacją geopolityczną kraju, a jednocześnie uświadamia potencjalne istnienie błędów w treści, rzutujące na wyniki analiz przeprowadzanych z wykorzystaniem tych map.

Wopisywanychanalizach wykorzystanokilka cywilnych map topograficznych, widocznych na rycinie 1 - mapy w układzie „1965” (1:10 000, 1:25 000), tzw. „obrębówkę” (1:25 000) oraz, jako materiał referencyjny, współczesną mapę w układzie „1992” (1:10 000). Mapy, jak wspomniano, są bardzo dobrym materiałem do analizy zmian i pozostałości minionej przestrzeni w topografii. Ze względu jednak na niektóre ich cechy (m.in. generalizację) oraz fakt, że zakres poszukiwanych treści wykracza poza zakres treści map (np. w zależności od skali brak jest słupów energetycznych, zgeneralizowane są elementy zabudowy poprzez uogólnienie grupy zabudowań do sygnatury gospodarstwa bądź pominięcie niewielkich powierzchniowo sadów), materiałem pomocniczym może być dokumentacja fotograficzna oraz zdjęcia lotnicze. Zwłaszcza te drugie, ze względu na profesjonalny i systematyczny ${ }^{4}$ wymiar oraz brak generalizacji (klisza rejestruje całą widoczną treść), pełnią nieocenioną funkcję $\mathrm{w}$ analizach zmian środowiska. W opisywanym przypadku wykorzystano zdjęcie z lat siedemdziesiątych XX w., czyli sprzed powstania osiedli z wielkiej płyty.

Do materiałów dodać należy wspomniane fotografie (archiwalne i - jako odniesienie - współczesne) oraz bieżące zobrazowania satelitarne, pozyskiwane do analiz przez usługe WMS 5 . Ważną rolę w analizach odgrywa kon- frontacja prac kameralnych z wynikami prac terenowych. Powinna ona odbywać się w dwu etapach. Pierwsze rozpoznanie terenowe wspomagane mapa, pozwala wstępnie zapoznać się z obszarem badań i wytypować elementy, które stanowić mogą pozostałości dawnej przestrzeni. Jako przykład takich elementów posłużyć moga drzewa owocowe w strefie zabudowy (pozostałość sadu), niezainwestowana działka otoczona przez budynki (nieuregulowany stan własności gruntu po dawnym gospodarstwie lub polu), elementy kulturowo-bytowe (kapliczka, piwnica ziemna) czy nietypowy układ dróg. Drugi etap prac terenowych powinien mieć miejsce już po pracach kameralnych, gdy materiały są skorelowane i wykonano analizy przestrzenne, które stanowią podpowiedź, na co zwrócić uwagę w terenie (i sprawdzić, czy kameralne dociekania znajdują potwierdzenie w rzeczywistej przestrzeni).

W analizowanym przypadku większość prac kameralnych wykonana została w oprogramowaniu z grupy GIS (ArcMap v9.2). Pakiety tego typu pozwalają na łatwe nakładanie materiałów o różnych początkowych własnościach geometrycznych i ewentualną korektę kartometryczności. Niestety sam proces korekty nie zawsze jest zadowalający, choć na poziomie metrycznych dokładności analiz środowiskowych opisywanego typu, całkowicie zaniedbywany. Błędy wynikają z konstrukcji map, niepewności matematycznej odwzorowań dawnych map cywilnych, ale także różnic algorytmów przeliczania i definicji w samych programach GIS ${ }^{6}$. Korekta

${ }^{2}$ W. Grygorenko, Kartografia polska w latach 1945-1990 w potrzasku reorganizacji i cenzury, „Polski Przegląd Kartograficzny”, 23 (1991), nr 1-2, s. 1-7.

${ }^{3}$ B. Konopska, Cenzura $w$ kartografii okresu PRL na przykładzie map do użytku ogólnego, „Polski Przegląd Kartograficzny”, 39 (2007), nr 1, s. 44-57.

${ }^{4}$ Zdjęcia lotnicze wykonywane są celowo, metodycznie, według określonego planu nalotu i z zachowaniem jednolitych dla serii zdjęć parametrów kamery i lotu.

${ }^{5} \mathrm{Z}$ racji, iż jako materiał referencyjny wybrano współczesną mapę topograficzną w układzie „1992”, naturalnym wyborem były ortofotomapy dostępne w serwisie Geoportal (www.geoportal.gov.pl) i udostępniane właśnie przez usługę WMS.

${ }^{6} \mathrm{~K}$. Nieścioruk, Zróżnicowanie kartograficznych materiatów źródłowych na przykładzie planów miast w systemie samochodowej nawigacji satelitarnej, „Scientific Bulletin of Chełm. Section of Technical Sciences", 1 (2008), s. 127-132. 

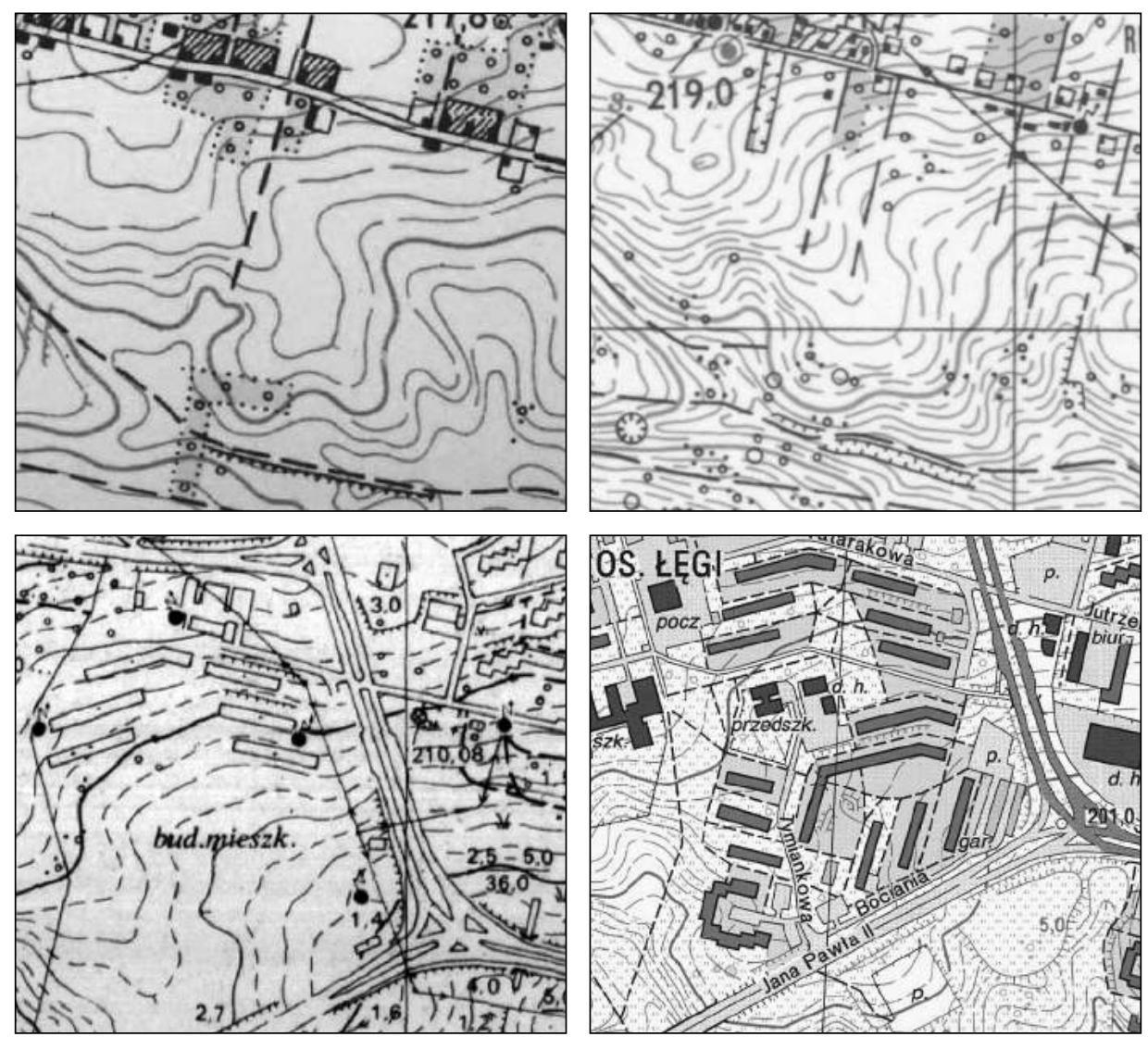

Ryc. 1. Mapy (zmniejszone) wykorzystane w analizie, na górze od lewej: „obrębówka” (1:25 000, 1961), mapa topograficzna w układzie „1965” (1:25 000, 1978); na dole od lewej: mapa topograficzna w układzie „1965” (1:10 000, 1985), mapa topograficzna w układzie „1992" $(1: 10000,2001)$

map o wątpliwych podstawach matematycznych (np. wspomnianej „obrębówki”) możliwa jest tylko poprzez transformację, w oparciu o szczegóły terenowe odniesione do ich rzeczywistego położenia. W programach GIS możliwa jest także integracja danych różnego rodzaju i różnego pochodzenia. Mogą to być obrazy rastrowe map topograficznych, wektorowe dane z prac terenowych (dane GPS) oraz prac kameralnych (wektoryzacja treści map), a także informacje pobrane $\mathrm{z}$ internetu, choćby przez wspomnianą usługę WMS. Przede wszystkim jednak programy GIS udostępniają cyfrowe (a więc efektywne i matematycznie określone w ramach zadanego modelu) narzędzia ilościowych i jakościowych analiz przestrzennych oraz wizualizacji.

\section{Analizy wizualne}

Po nałożeniu na siebie map topograficznych i zdjęcia lotniczego, posiłkując się wcześniejszym wstępnym rozpoznaniem terenowym, udało się wyodrębnić lub potwierdzić wyodrębnienie kilku elementów dawnej wsi w przestrzeni wspomnianych osiedli.

1. Sady. Zwarty obszar nadal owocującego i zachowującego czytelny układ sadu znajduje się na skraju osiedla Łęgi (ryc. 2). Pojedyncze drzewa owocowe lub mniejsze ich skupiska zlokalizowano wzdłuż ulicy Tatarakowej oraz Jutrzenki.

2. Układ ulic. Dawna główna droga przez wieś Rury pokrywa się na znacznym odcinku z główną ulicą osiedla Ruta, ul. Jutrzenki 
(odstępstwo nie dotyczy charakteru przebiegu, jest jedynie przesunięciem wynikającym częściowo prawdopodobnie z ukształtowania terenu) oraz ul. Tatarakową w osiedlu Łęgi (ryc. 3). Nastąpił tu też interesujący przykład zmiany hierarchii. Droga główna pokrywa się, jak wspomniano, z główną ulicą w jednym z osiedli, natomiast przechodząc na drugie osiedle jest przecinana przez rozdzielającą osiedla ulicę dwupasmową. Ulica ta zamyka perspektywę ciągu dawnej drogi (obecnie przejazd jest zamknięty).

3. Zabudowania. Jedynie dwa gospodarstwa dawnej wsi Rury zachowały się w dzisiejszej przestrzeni. Jedno $\mathrm{z}$ nich położone jest peryferyjnie, praktycznie poza terenem osiedla, drugie natomiast znajdujące się przy istotnym skrzyżowaniu, zmieniło radykalnie swój charakter (pozostał jedynie dom mieszkalny, choć jeszcze w latach osiemdziesiątych XX wieku, gdy istniało już osiedle mieszkaniowe, zachowane były także budynki gospodarcze) i zostato otoczone zabudową komercyjną, samo także współdzieląc tę funkcję (ryc. 4). Jest to ciekawy przykład dostosowania do zmieniających się warunków i odnalezienia się mieszkańców w nowej rzeczywistości. Słabo czytelna jest pozostałość trzeciego gospodarstwa - ziemna piwnica dobrze widoczna jeszcze w latach dziewięćdziesiątych XX wieku.

4. Pojedyncze drzewa. Krajobraz wsi rozlokowanych wzdłuż dróg tworzą m.in. charakterystyczne, dużych rozmiarów drzewa. Kilka z nich, z racji wysokości oraz położenia przy drodze, która zamieniona została w osiedlową
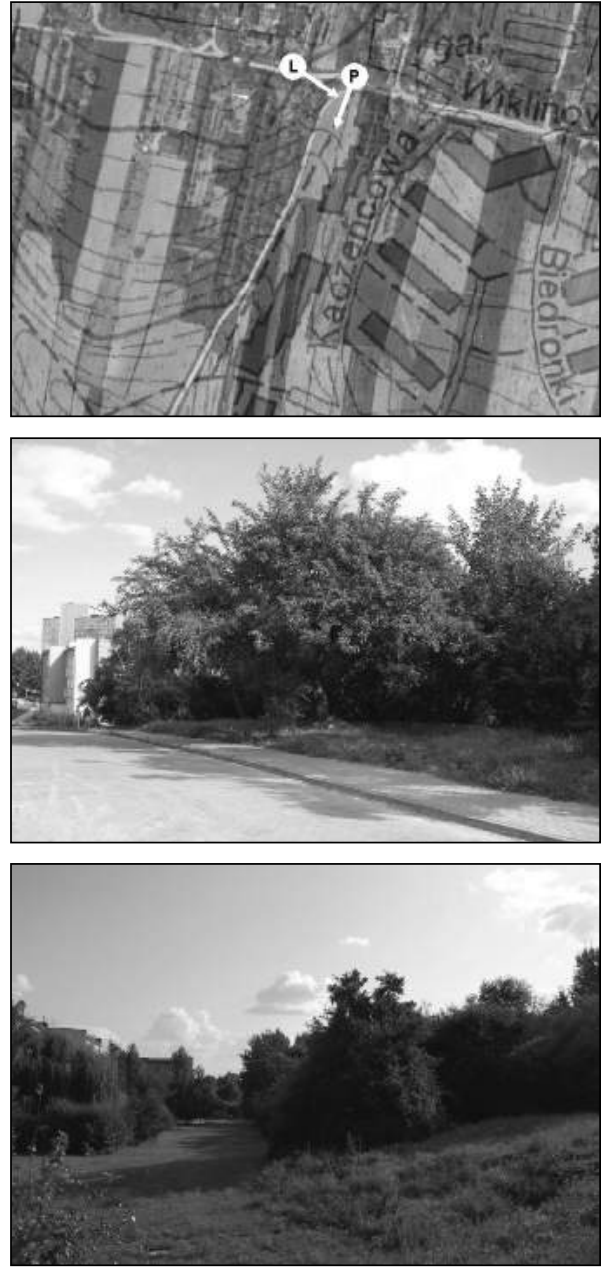

Ryc. 2. Sad w os. Łęgi. Na wspótczesną mapę topograficzną nałoziono zdjęcie lotnicze z lat 70., strzatkami oznaczono miejsca i kierunki wykonania zdjęć widocznych niżej ( $L$-zdjęcie górne, $P$-zdjęcie dolne)
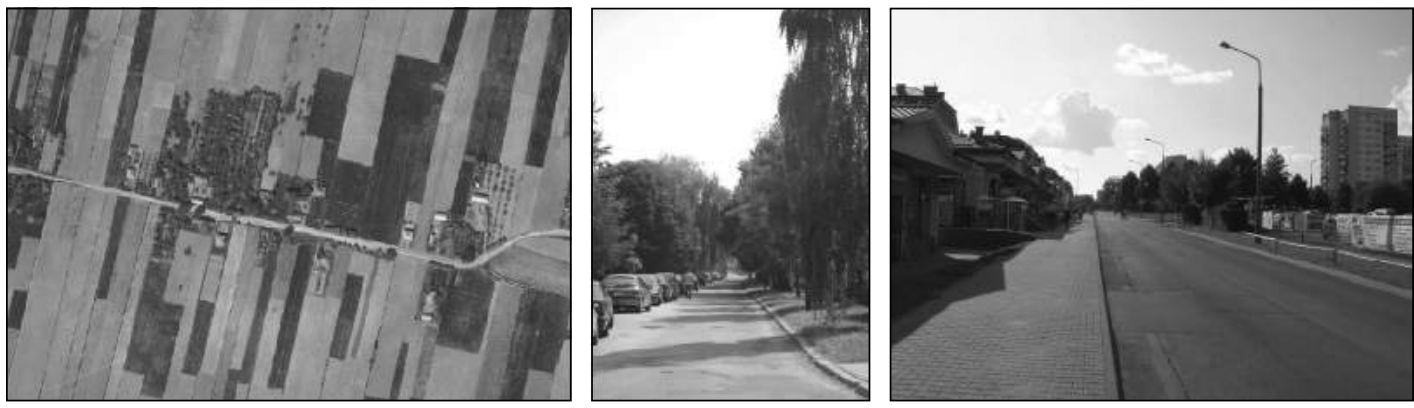

Ryc. 3. Gtówna droga przez wieś Rury. Widok na zdjęciu lotniczym oraz obraz jej dwu odcinków dziś - zdjęcie lewe to osiedlowa ul. Tatarakowa, zdjęcie prawe to ul. Jutrzenki, przelotowa droga przez osiedle 

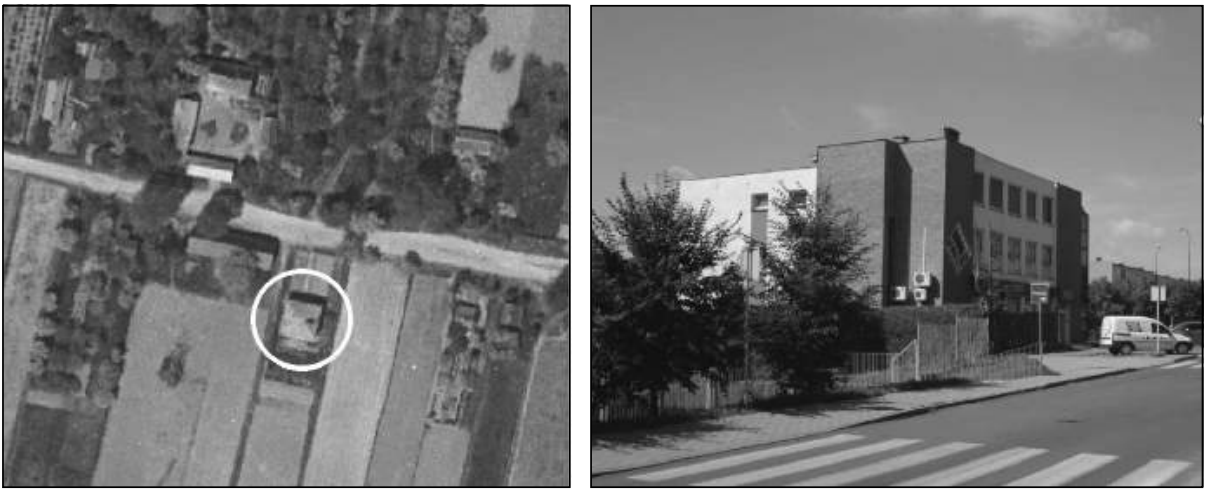

Ryc. 4. Dom - pozostałość dawnej wsi, dziś otoczony przez lokale usługowe (fotografia po prawej). Na zdjęciu lotniczym dom oznaczony kótkiem
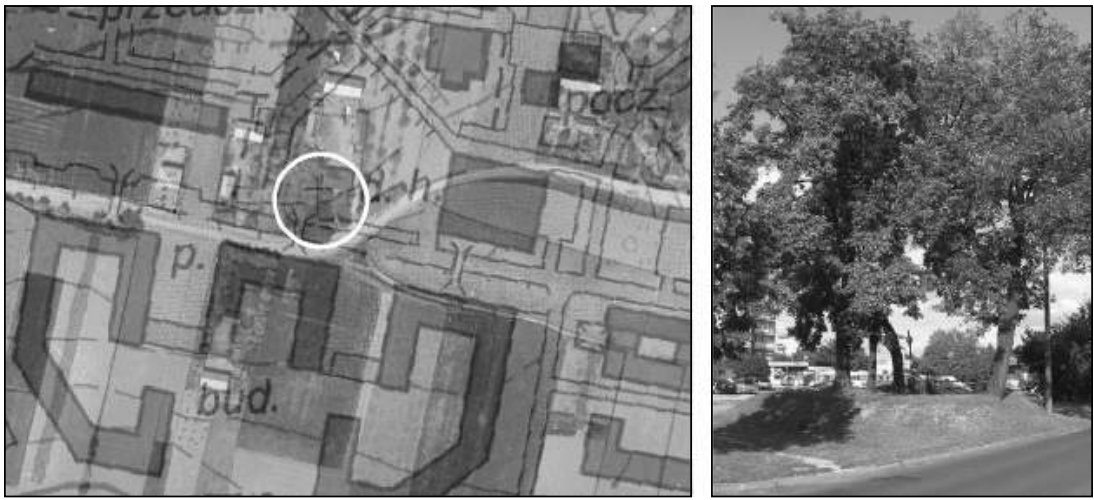

Ryc. 5. Przydrożny krzyż (oznaczony kótkiem) na wspótczesnej mapie z nałożonym na nią archiwalnym zdjęciem lotniczym. Po prawej - stan obecny

ulicę (bezpośrednie sąsiedztwo ulicy nie jest zabudowane, a więc nie zostały one wycięte), zachowało się do dziś.

5. Elementy kulturowe. W analizowanym przypadku występuje tylko jeden taki element - przydrożny krzyż w otoczeniu drzew. Dawniej stał on na skrzyżowaniu dróg, obecnie rozwidlenie to nie funkcjonuje (ryc. 5).

\section{Analizy ilościowe}

Wstępem do analiz ilościowych była wektoryzacja danych pozyskanych z map i zdjęcia. Dane rastrowe w opisywanych analizach były jedynie zobrazowaniami bez przypisanych wartości atrybutów przyrodniczych ${ }^{7}$, a model wektorowy został zastosowany m.in. jako etap pośredni w uzyskaniu modelu terenu. Zwek- toryzowano poziomice $\mathrm{z}$ trzech map topograficznych i dla analizowanego obszaru utworzono cyfrowe modele terenu oraz - na ich podstawie - cieniowanie rzeźby terenu. Cięcie poziomicowe map wynoszące $1,25 \mathrm{~m}$ nie pozwoliło na zaobserwowanie drobnych zmian, jednak powierzchnia utworzona jako różnica poziomów modeli terenu stanowi interesujący obraz. Przede wszystkim, analizując zmiany o wartościach większych niż wspomniane cięcie, odnajdujemy ewidentne przekształcenia antropogeniczne związane $\mathrm{z}$ większymi konstrukcjami ziemnymi, jak np. wsparcie mostu

${ }^{7}$ Piksel reprezentuje jedynie kolor, a więc tworzy ilustrację. Nie ma wartości w rozumieniu rastrowego modelu danych wykorzystywanego $w$ analizach. 
lub wyrównanie terenu pod budowę bloków w strefie rozległej suchej doliny. Niewielkie różnice występują też w samych dolinach, co można próbować wiązać ze zmianą charakteru użytkowania terenu (brak uprawy, zmiana akumulacji i erozji). Rycina 6 przedstawia wynik operacji odjęcia od siebie modeli terenu opracowanych na podstawie mapy współczesnej w układzie „1992” i mapy w układzie „1965”.
Rycina 7 pokazuje natomiast wynik analogicznej analizy dla modeli opartych na mapie w układzie „1965” i mapie obrębowej. Bardzo duże (znacznie większe niż na poprzedniej rycinie) różnice nie są oczywiście wynikiem zmian $\mathrm{w}$ terenie, gdyż $\mathrm{w}$ tym czasie nie nastąpiły żadne istotne przekształcenia (przez cały okres między powstaniem obu map znajdowała się tu wieś). Jest to efekt sposobu, w jaki powstała

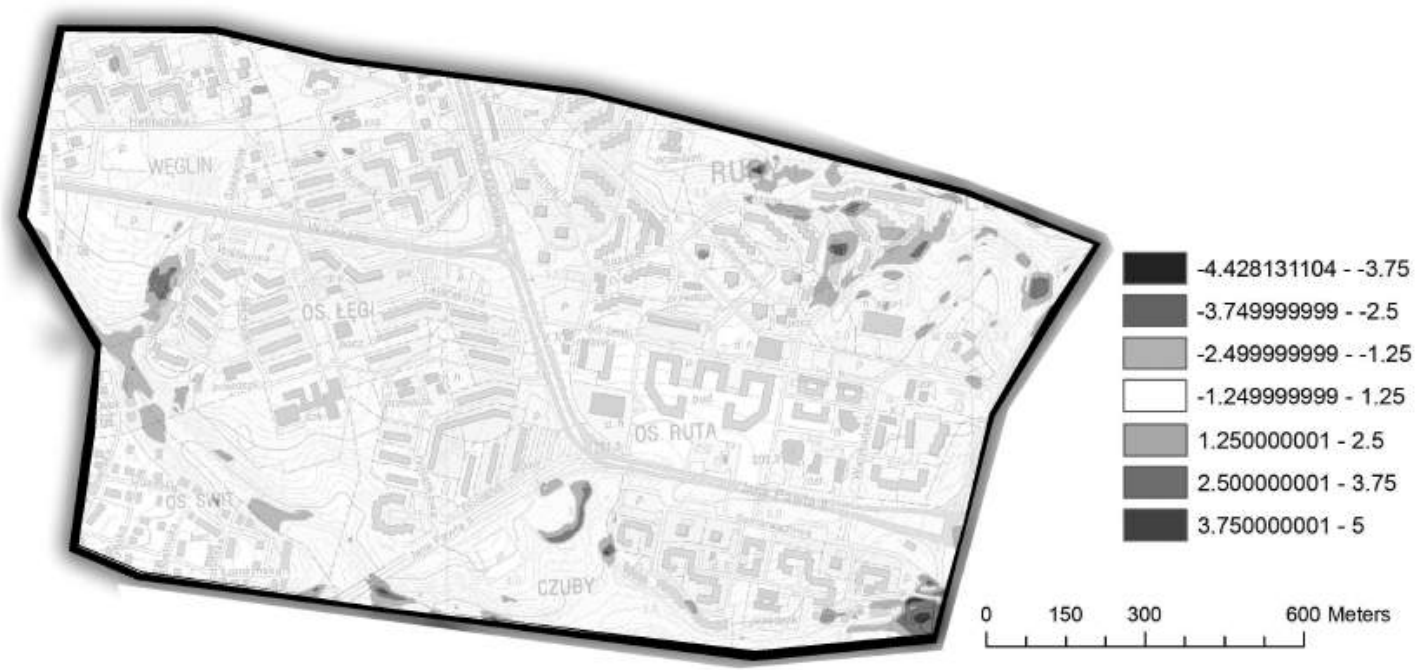

Ryc. 6. Różnica wysokości na analizowanym obszarze (w metrach) wg modeli terenu utworzonych w oparciu o mapę w układzie "1992” i w układzie „1965”

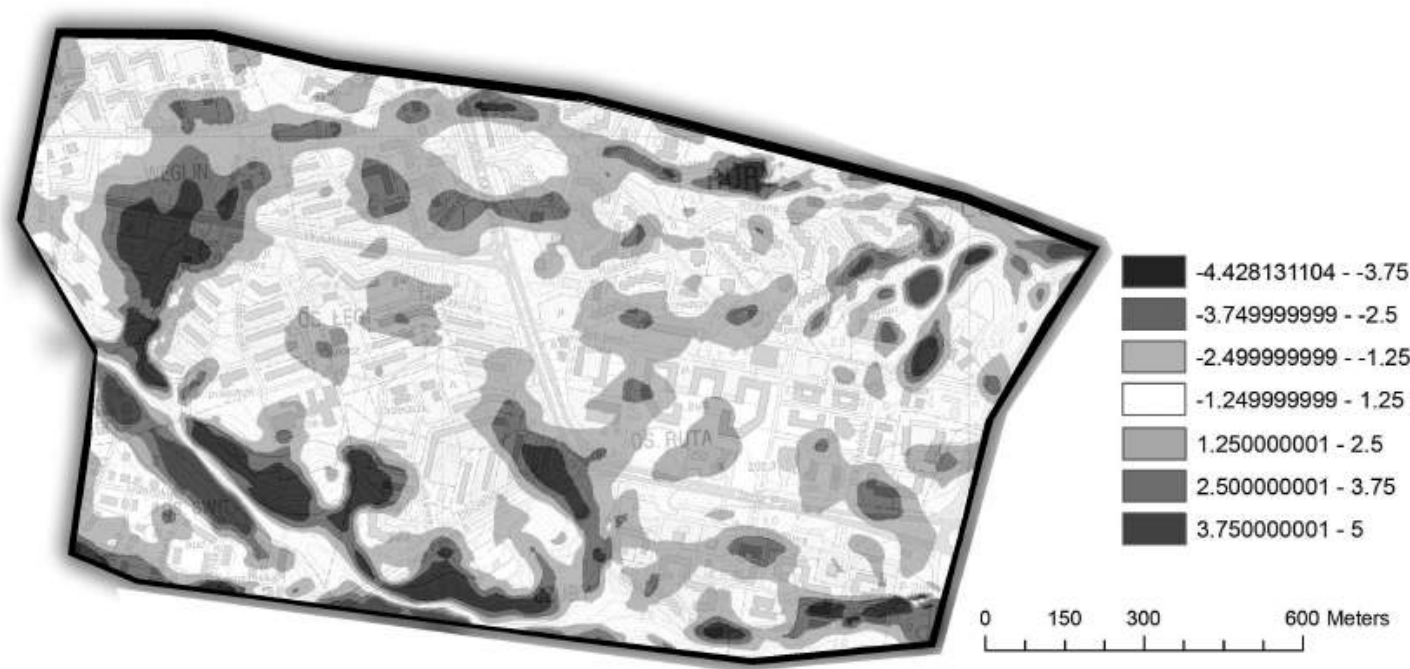

Ryc. 7. Różnica wysokości na analizowanym obszarze (w metrach) wg modeli terenu utworzonych w oparciu o mapę w układzie „1992” i tzw. „obrębówkę" 
mapa obrębowa - cięta, sztukowana i fałszowana, nieprzedstawiająca rzeczywistych odległości i kierunków ${ }^{8}$. Choć jej właściwości są powszechnie znane, to powyższa analiza pozwala stwierdzić, że możliwe jest korzystanie z niej tylko w sytuacji, gdy zostanie ona "naciągnięta” na szczegóły topograficzne - obiekty o charakterze punktowym można wtedy traktować jako dość poprawnie przedstawione. Mowa tu na przykład o gospodarstwach, podczas gdy kompletnie niewiarygodne są chociażby powierzchnie (jak właśnie teren).

\section{Wizualizacje}

Analizy w systemach GIS wymagają stworzenia przestrzennej bazy danych. Elementem bazy mogą być wektorowe informacje odczytane $\mathrm{z}$ rastrowych podkładów i zdjęć. O generowaniu cyfrowego modelu dawnego terenu była mowa powyżej. Mapa wraz ze zdjęciem lotniczym umożliwiają także zakodowanie danych o działalności człowieka, jak na przykład drogach, czy informacje o użytkowaniu ziemi, odczytane z mapy i doprecyzowane na podstawie zdjęcia lotniczego (np. rozróżnienie nieużytków, zwykle nieklasyfikowanych na dawnych mapach topograficznych oraz pól, łąk i sadów). Szczególnie cenną cechą zdjęcia jest brak jego generalizacji. Mapa umożliwia zdobycie informacji o istnieniu gospodarstwa, ale to zdjęcie pozwala wyróżnić poszczególne budynki, wydzielić ich typy (gospodarczy, mieszkalny) czy nawet (przy zdjęciu dobrej jakości) liczbę kondygnacji i rodzaj konstrukcji (drewniana, murowana). Tak rozbudowana baza jest pierwszym krokiem do stworzenia wizualizacji - trójwymiarowego modelu dawnej przestrzeni. Dostęp do informacji o typie budownictwa w danym okresie na danym terenie, a przede wszystkim dostęp do dokumentacji fotograficznej $\mathrm{z}$ danego okresu (zdjęć naziemnych), pozwala na wykonanie modelu nieistniejącego krajobrazu (ryc. 8). Przy pracach tego typu zachodzi konieczność posiłkowania się opracowaniami z innych dziedzin, jak architektura czy etnografia, które to dostarczają typologii zabudowy oraz szczegółów konstrukcyjnych istotnych w kształtowaniu trójwymiarowych modeli budynków.
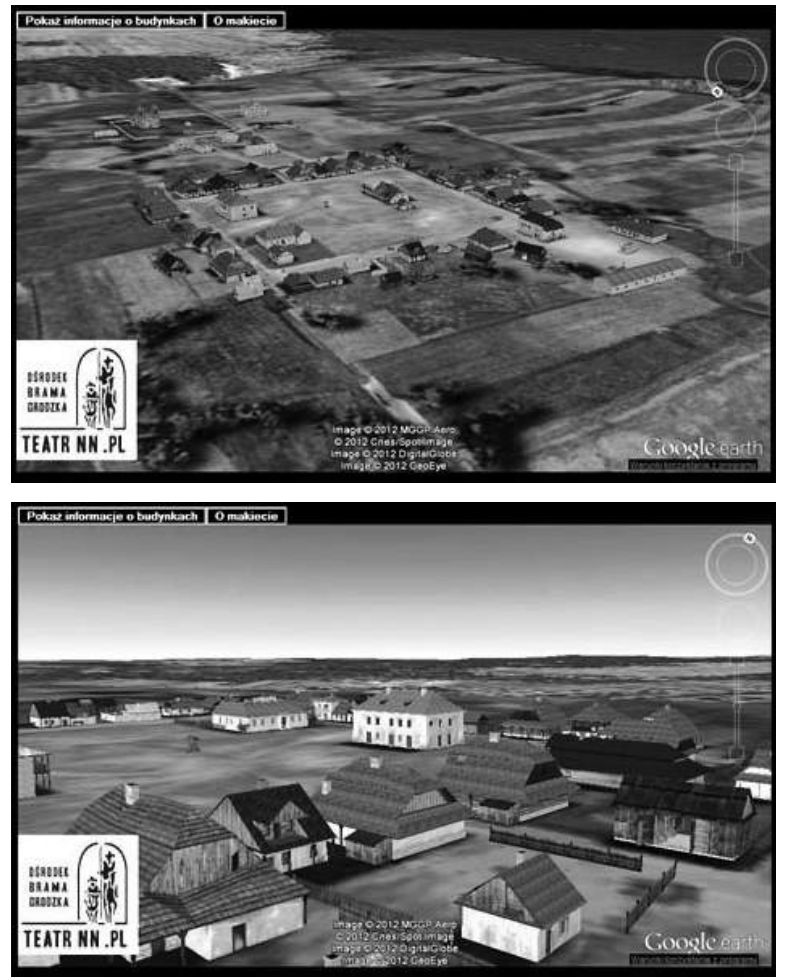

Ryc. 8. Wirtualna makieta dawnego Józefowa na Roztoczu opracowana w oparciu m.in. o dokumentację fotograficzną, tekstową i mapy (źródto: Ośrodek „Brama Grodzka - Teatr NN”, dostęp: http://www.teatrnn.pl, 15 lutego 2013)

\section{Podsumowanie}

W tytule artykułu zawarto określenie „mapy archiwalne”, a analiza, do której wykorzystano owe mapy dotyczyła niedalekiej przeszłości drugiej połowy ubiegłego wieku. Same mapy, choć nie tak stare, przedstawiają już wartość historyczną. Nie chodzi tu oczywiście o treść i ukazany stan środowiska, bo te zmieniają się w naturalny sposób (właściwie każda mapa w momencie wydania może być uznana za historyczną, pokazującą stan z przeszłości). Mapy te są dokumentem swojej epoki, dowodem specyficznych warunków, w jakich rozwijała się polska kartografia topograficzna (i nie tylko) okresu powojennego - cenzura treści, celowe zafałszowania podstaw matematycznych (a więc samej istoty, bazy map), utrudniony dostęp. Powyższe

${ }^{8}$ W. Grygorenko, Kartografia polska, s. 3. 
okoliczności uprawniają użycie wobec tych map określenia nie „archiwalne”, a - zarezerwowanego dla domeny historii kartografii - „dawne”.

Mapa dawna może być nie tylko materiałem źródłowym do badań, ale także obiektem badawczym samym w sobie. Gdy jest źródłem informacji o przeszłej sytuacji, należy - w miarę możliwości - posiłkować się także innymi materiałami. W przypadku analiz opisanych $\mathrm{w}$ artykule, gdy przedmiotem badań jest niedaleka przeszłość i zmiany zachodzące w krajobrazie podmiejskim w dynamicznie zmieniającym się środowisku powojennej Polski, materiałów takich może być wiele. Ważną rolę odgrywają fotografie naziemne, dokumentujące środowisko, zawierające szczegóły trudne lub niemożliwie do odtworzenia na podstawie map, jak np. elementy kulturowe (typ zabudowy, kapliczki itp.). Bardzo cenne informacje odczytać można ze zdjęć lotniczych, które - nie będąc zgeneralizowane - dostarczają danych nieobecnych na mapach, co może być istotne zwłaszcza przy konstruowaniu wizualizacji dawnej przestrzeni.

Dane do analiz oraz do wizualizacji pochodzić powinny także z jeszcze jednego źródła, a mianowicie z badań terenowych. Praca do-

\section{Literatura}

Grygorenko W., Kartografia polska $w$ latach 1945-1990 w potrzasku reorganizacji i cenzury, „Polski Przegląd Kartograficzny”, 23 (1991), nr 1-2, s. 1-7.

Konopska B., Cenzura $w$ kartografii okresu PRL na przyktadzie map do użytku ogólnego, „Polski Przegląd Kartograficzny”, 39 (2007), nr 1, s. 44-57.

\section{Źródła kartograficzne}

M-34-34-A-c-1 (Lublin-Rury), mapa topograficzna 1:10 000, 2001.

136.31 (Lublin), mapa topograficzna, 1:25000, 1978. tycząca zmian środowiska nie może opierać się wyłącznie na badaniach kameralnych. Rozpoznanie terenowe, dokumentacja fotograficzna i dane pozyskane za pomocą odbiornika GPS są cennym uzupełnieniem analiz.

W badaniach z zakresu historii kartografii często napotykamy na konieczność sięgania do opracowań nauk innych niż kartografia czy nawet innych niż nauki przyrodnicze. Zwykle jest to historia, ale postulat interdyscyplinarności badań jest aktualny niezależnie od przeznaczenia i tematu analiz, w których wykorzystywane są mapy dawne. Zakres dziedzin jest szeroki od archeologii, przez etnografię i architekturę, po grafologię czy historię sztuki.

Dla kartografa opisane analizy będą interesujące, gdyż pozwalają poznać zastosowanie map z punktu widzenia specjalistów innych dziedzin. Geograf zajmujący się środowiskiem dostrzeże w powyższych analizach narzędzie badania zmian, jakie zaszły w przestrzeni i wyrażania ich w sposób analityczny. Wizualizacje wyników analiz natomiast, oprócz efektownej poglądowości, mogą być interesujące dla szerokiego grona specjalistów badających przestrzeń, jej zmiany i efekty ludzkiej aktywności w tej przestrzeni.

Nieścioruk K., Zróżnicowanie kartograficznych materiatów źródtowych na przyktadzie planów miast $w$ systemie samochodowej nawigacji satelitarnej, „Scientific Bulletin of Chełm. Section of Technical Sciences", 1 (2008), s. $127-132$.

Radzik T. i in., Lublin. Dzieje miasta, t. 2, XIX i XX wiek, Lublin 2000.

\subsection{1 (Lublin), mapa topograficzna}

1:10 000, 1985.

Powiat Lublin, arkusz IV, mapa 1:25 000, 1961. Zdjęcie lotnicze 1:16 000, 1976. 


\section{Archival cartographic materials as a source to reconstruct the space of old villages in the zone of urban housing}

\section{Summary}

The paper describes a possibility of using post-war cartographic materials (but not only) in a process of tracing and analyzing the remnants of the past landscape in urbanized areas (the case of Lublin) and virtual revival of such landscapes. The process of gathering and selecting materials is described, including cartometric quality discussion and an idea of supporting analyses with field works is discussed. The analyses mentioned above are divided into visual (qualitative) and quantitative ones. The former includes overlaying cartographic materials to check for remnants and to support the hypothesis posed during field-works. The latter - a comparison of digital elevation models based on early maps. The final part deals with constructing $3 \mathrm{D}$ visualization of past landscape based on maps, aerial and regular photographs and additional, non-cartographic materials.

Słowa kluczowe: geografia historyczna, dawny krajobraz obszarów zurbanizowanych, dawny krajobraz w wizualizacji 3D.

Keywords: historical geography, the past landscape of urbanized areas,

$3 \mathrm{D}$ visualization of the past landscape.

dr Kamil Nieścioruk - adiunkt w Katedrze Inżynierii Kształtowania Środowiska i Geodezji

Uniwersytetu Przyrodniczego w Lublinie,

(e-mail: kamil_niescioruk@02.pl,www: www.niescioruk.ppa.pl). 